\title{
The Effect of Critical Thinking on Developing Argumentative Essays by Iranian EFL University Students
}

\author{
Mansoor Fahim \\ Islamic Azad University, Science and Research Branch, Tehran, Iran \\ Email: dr.mfahim@yahoo.com \\ Pantea Hashtroodi \\ Islamic Azad University, Science and Research Branch, Tehran, Iran \\ Email: pantea_8roodi@yahoo.com
}

\begin{abstract}
This study tried to find out whether or not teaching techniques of critical thinking through writing to the Iranian English students at university level can lead them develop writing argumentative essays. We received the help of 63 university students in two classes at Islamic Azad University, with the average age of 21 whose major were translation. Those falling within two SD above and below the mean on TOEFL were chosen. Participants were asked to write two five-paragraph argumentative essays; one at the beginning of the term, and the other one after 6 sessions. Since the second session, for about four sessions and each session 30 minutes, the experimental group was received a treatment. Participants' papers were scored based on Unrau's scoring guide by two English teachers. T-tests were used to check the differences between experimental and control groups. This study's implication is that techniques of critical thinking can help the students to become critical thinkers because the improvement was positive, yet it cannot help them to write more argumentative essays, for the fact that the improvement was not significant.
\end{abstract}

Index Terms — critical thinking, argumentative essays, thinking through writing

\section{INTRODUCTION}

In recent years, as McGregor (2007) notes working on the critical thinking and its application in education have been developed mostly by Dewey's early writings. Dewey (1910) believed that critical thinking, in its best sense, should make the basis and foundation of all kinds of thoughts. Glaser (1941), as cited in McGregor (2007), expands this early notion of critical thinking to include the knowledge of the methods of logical inquiry and reasoning. Fisher (1990) recognizes the important universal nature of critical thinking and introduces it as the cornerstone of any academic maneuver and skills at learning a language such as reading and writing.

A major part of a formal education, in recent years, is essays. Secondary students are taught structured essay formats to improve their writing skills, and admission essays are often used by universities in selecting applications. Essays are used to judge the mastery and comprehension of material in both secondary and tertiary education, so students are asked to explain, comment on, or assess a topic of study in the form of an essay. Usually academic essays are more formal than literary ones. They may allow the presentation of the writer's own views, yet this is done in a logical and factual manner with the use of the first person often discouraged. (Glenn, 2004)

Education should aim to support the development of independent thinkers who are discerning problem solvers, and can use a range of cognitive skills and strategies, including critical thinking, to solve problems (McGregor, 2007). Summer (1940) defines critical thinking as the examination and test of propositions of any kind which are offered for acceptance, in order to find out whether they correspond to reality or not. Unrau (1997) defines critical thinking under the influence of Ennis' works as "a process of reasoned reflection on the meaning of claims about what to believe or what to do" (p.14).

\section{A. Theories behind This Study}

Two main theories related to this study are as follows: 1) theory of reflective language teaching, and 2) critical pedagogy. Both of them are categorized into pedagogy of being and are somehow umbrella terms for critical thinking.

\section{B. Definitions of Reflective Teaching}

Farrell (2007) believes that there are many different definitions of reflective teaching, but most of them can be contained within two main stances to reflective teaching. He notes that one of these stances emphasizes reflection only on classroom actions, while the other also includes reflections on matters outside the classroom. He gives definition of the former approach by quoting from Cruickshank and Applegate (1981, p.553) as a process that "helps teachers to 
think about what happened, why it happened, and what else could have been done to reach their goals". He cites Schulman (1987, p.19) in suggesting when a teacher "reconstructs, reenacts and/or recaptures the events, emotions, and the accomplishments" of his or her teaching, reflection happens. For the latter stance he states the definition by Jay and Johnson (2002) which maintains, the linking teaching to the larger community called critical reflection. This critical reflection involves the broader historical, sociopolitical and moral context of schooling therefore reflective teachers can consider themselves as agents of change. By this definition the latter stance considers the school culture that includes the context in which the schooling is taking place.

Also Mason (2008) says that reflective judgment plays an important and crucial role in today's complex world. He continues that "the goals of critical thinking and of life-long and life-wide learning appear frequently in the rhetoric of current educational reform in many societies across the globe.” (p.1)

\section{Types of Reflective Teaching}

According to Farrell (2007) there are three major types or moments of reflective practice where teachers can undertake reflection. The first moment is called reflection-in-action and it happens during the event, such as classroom teaching. The second moment is called reflection-on-action which is thinking about the event after it has happened. While the third moment is called reflection-for-action and it is where teachers think about future actions.

Reflection-on-action which is the second moment or type of reflection involves thinking back on what was done to find out how knowing-in-action may have contributed to an unexpected action; hence, it would come to mean some kind of metacognitive action (Farrell, 2007). Unrau (1997) notes students need some skills to get through school and to know how to function properly at work. Therefore, he says there should be a kind of vision based on the development of critical thinking that puts meaningful reflection on what is learned ahead of storing information and passing tests. Consequently based on what Unrau (1997), and Farrell (2007) say, the researchers come to the point that reflection-onaction and critical thinking have the same goal, and are somehow complementary.

\section{Definition of Critical Pedagogy}

Wink (2000) describes critical pedagogy as a way of knowing during which students not only read the word but also the world. Reading the world means closely examining power structures and our roles within them (Reyes and Vallone, 2008).

\section{E. Perspectives in Critical Pedagogy}

According to Reyes and Vallone (2008) critical pedagogy is not a list of things $\backslash$ to do in teaching, because it is not a teaching method, rather as the name implies, it is an art of teaching, or a way of teaching, in which the world is viewed through a critical lens.

They also note that critical pedagogy is not widely known by teachers, because of the standards-based educational environment in which teachers currently find themselves. They emphasize that objectives are defined already, and finding a way of teaching that encourages students to critically examine their reality can be a challenge.

Furthermore they mention that critical pedagogy cannot be examined without a discussion of Freire (1970) who wrote Pedagogy of the Oppressed in which he believes that education (at its worse) could be used to transmit knowledge working to favor the best interests of the oppressor.

\section{F. The Concept of Critical Thinking}

Garrison (1991) says that "in contrast to Sternberg's (1986) belief that there is a degree of consensus on the nature of critical thinking, McPeck (1981:1) states that 'it is not at all clear that people mean the same thing by critical thinking'" (p. 287).

Feuerstein (1999) mentions that critical thinking is one of the movements of thinking that was prominently developed during the 1980s with the idea and fact that schools should be less concerned with imparting information and requiring the memorization of empirical data. Feuerstein continues that the rationale behind critical thinking holds that an information society which is a society based on producing and promoting knowledge must be equipped with critical competence.

Williams (2005) believes that "critical thinking is important in all academic disciplines within democratic education, but it is indispensable in the field of teacher education" (p.164). he says that considering the number of students who go through our schools, eventually future teachers could affect the critical thinking skills of the whole society.

Lewis and Smith (1993), (as cited in Jeevanathan, 2005) distinguish between higher order thinking and critical thinking and problem solving. Jeevanathan mentions that Hager's (1991) distinction between low-level mental activities (for example, recalling, comparing and classifying) and high-level mental activities (for instance credibility evaluation, assumption identification and determination of the strength of arguments or claims), is by far more efficacious in the issue of dealing with critical thinking instead of higher or lower levels of critical thinking.

\section{G. Research Question}


This study's researchers believe that in Iran University students cannot write (properly) and develop argumentative essays, yet during their academic studies and for further education they need to write them. This study tried to find the answer to the following question:

Does Critical thinking develop writing argumentative essays by Iranian University EFL students?

\section{H. Null-Hypothesis}

The null hypothesis in this study is:

Hō: Critical thinking does not develop writing argumentative essays by Iranian University EFL students.

\section{THE REVIEW OF THE RELATED LITERATURE}

Bailin, Case, Coombs, and Daniels (1999) mention that frequently critical thinking is conceptualized in the case of skills, processes, procedures and practice. Daniels et al (1999) continue that great amount of educational literature refers to cognitive or thinking skills or equates critical thinking with certain mental processes or procedural moves that can be improved through practice. They further say that courses and conferences concentrate on the development of thinking skills and references to skills appear in much of the literature. They state that "even leading theorists in the area of critical thinking conceptualize critical thinking largely in terms of skill" (p. 270)".

Unrau (1997) defines critical thinking under the influence of Ennis' works as "a process of reasoned reflection on the meaning of claims about what to believe or what to do" (p.14). He explains that some forms of reasoning occurs when a thinker reflects upon statements, and before anyone embraces a claim, s/he is going to look for good reasons to do so.

Sharma (1995) thinks that "the vehicle of all thinking is language, and therefore, so it is of critical thinking" (p. 35). Sharma also explains that critical thinking depends on the vocabulary of the participants which direction the thinking in argument or in discussion or in the writing process will take.

According to Zainuddin and Moore (2003), there are different definitions of critical thinking, ranging from ones which envisage critical thinking as a broad construct which centers primarily on reasonable and reflective thinking and is focused on what to do or believe, while others view it more narrowly, specific to a certain content area.

Based on the definition of Kabilan (2000), creative and critical language learners are those who have cognitive abilities to carry out tasks affectively. They must be able to carefully and deliberately determine to accept, reject or suspend judgment about a claim. In the mean time, critical language learners must be able to cite and identify good reasons for their answers and opinions; they should also correct themselves and others' methods and procedures, and cope with regularities, uniformities, irregular circumstances, special limitations, constraints and over-generalizations.

Wright (2002) says "when I discovered critical thinking, my teaching changed" (p.9). He notes that instead of focusing on questions which had "right" answers, he wanted children to think through situations where the answer was in doubt. He believes that critical thinking is beneficial in social studies along with music, in science when dealing with environmental problems, deciding whether animals should be used in research, or figuring out the best way to test a hypothesis, in literature study during judging the actions of characters in stories, and in all subject areas when deciding which sources of information were most reliable or how best to present information.

Also according to Wright (2002, p.43) the definition of critical thinking consists of the following:

1. Critical thinking is synonymous with problem solving.

2. Critical thinking is a skill.

3. Critical thinking involves asking questions at higher levels of Bloom's taxonomy-i.e. analysis, synthesis, and evaluation.

4. Critical thinking means helping students criticize the arguments and conclusions of others; it is always negative. ("Critical" in the sense and meaning with which it is used in the term critical thinking is not simply negative.)

5. Critical thinking is applied only to factual matters; it is not applicable to values.

6. Critical thinking is not related to creative thinking.

Fisher (1990) notes that "Critical thinking describes how something is being thought about"(p.65). He adds that learning to think critically means: (a) learning how to question, when to question and what questions to ask, and (b) learning how to reason, when to use reasoning and what reasoning methods to use. Finally he mentions that being a critical thinker one should develop certain attitudes, such as a desire to reason, willingness to challenge and a passion for truth.

\section{A. Some Studies Based on Critical Thinking}

Kabilan (2000) in his article which is called Creative and Critical Thinking in Language Classrooms notes that only using the language and knowing the meaning is not enough, in order to become proficient in a language, learners need to use creative and critical thinking through the target language. He also believes that creative and critical thinking skills should not be taught separately as an isolated entity, yet embedded in the subject matter and presented in curriculum. Then he concludes that most of the teachers ignore the capabilities of their learners, and disregard learners' views and opinions; therefore, the learners would not be able to train and use their thinking skills. In the end he states that the remedy would be changing teachers' pedagogical views and choosing a more flexible attitude towards their teaching. 
Kabilan (1999) says that Pedagogy of Question which is about posing questions to learners and listening to learners' questions can lead to producing critical and creative language learners that is by no means an easy task. Greenlaw and Deloach (2003) believe that in order to teach critical thinking effectively, an instructor must first be able to define it in ways appropriate to both the field of study and the medium to be used.

Scardamalia and Bereiter (1986, as cited in Unrau, 1997) in the planning of essays tested the effectiveness of an intervention strategy designed to facilitate reflective and critical thought. In intervention strategy they printed sentence openers, such as "A good point on the other side of the argument is that...", on index cards and gave them to students to use when planning their writing. They expected that students would finally internalize this external aid. In their study they found that the essays of students who received the cues displayed significantly more evidence of reflective thinking than those of students who did not receive the cues.

\section{B. Essay Writing}

"Essay writing is at the heart of most academic study" (Warburton, 2007, p.11). He thinks that talking about what you know is not enough; hence, you need to be able to make a clear and well-argued case in writings, based on appropriate research. He also believes that skills are built on good habits that are patterns of behavior that you don't need to think about, usually because you have practiced them many times before. And once you have got into a good habit, life gets easier. He mentions that if someone has a reasonable grasp of her/his subject and the will-power to practice writing, s/he can make significant improvements very quickly. "If you want to improve, then you need to write, not just read about writing." (p.3)

\section{What is 'Argument' in an Argumentative Essay?}

Bowell and Kemp (2002) define arguments as "to attempt to persuade by giving good reasons is to give an argument" (p.2). They further mention that critical thinkers primarily should be interested in arguments and whether they succeed in providing us with good reasons for acting or believing. They mention that it is surprising to think of an 'argument' as a term for giving someone a reason to do or believe something.

\section{Methodology}

This study is a kind of experimental research. Although randomized assignments of subjects to groups are ideal, it was not possible in practice for the researchers to do so in this study. Therefore they chose nonrandomized control group, pretest posttest design which is categorized under the quasi-experimental designs.

\section{A. Participants}

At the beginning of the study there were 63 freshmen university students in two essay writing classes in Islamic Azad University, South Tehran Branch with the same professor. After TOEFL test was administered the students who scored 2 standard deviations above and below the mean on the TOEFL were selected for the study. In this case one of the participants was dropped. Therefore the research was done with 59 homogeneous students.

\section{B. Instruments}

In order to measure the homogeneity of the students section two of the TOEFL test which consists of two parts of structure questions and written expression questions was administered. Due to practical reasons such as not having language laboratory for playing the $\mathrm{CD}$ or cassettes of the listening section available at the time of doing this study, the listening comprehension section was not administered. Furthermore, the time limitation did not allow the researcher to administer all other sections.

Section two of the TOEFL has got two parts. The first part has questions that are about structure, and the second part has written expression questions. The students answered them in 25 minutes.

Thesis-Analysis-Synthesis key (TASK) which is developed by Unrau (1997) was given to the students as a treatment. Also two passages of the book called FOR AND AGAINST by L. G. Alexander (1968) were given to the participants as a supplementary to the treatment.

The whiteboard was also used as an instructural aid for explanation of some parts.

\section{Procedure, Data Collection, and Data Management}

Section two of the TOEFL was copied and distributed to the students of the two groups on the first session of the study. Both experimental and control groups answered them in 25 minutes on the answering sheets, and then the papers were collected. After that students were asked to write a five paragraph argumentative essay on the same subject which is Advantages and Disadvantages of Internet, in about 30 minutes. The students' essays were scored based on Unrau's scoring guide by two English teachers.

Then the professor in 4 sessions taught the students English tenses, rules of writing five paragraph essays, and sentence connectors on both groups based on their course. Only the experimental group received the treatment. In detail saying, for about 4 sessions the students on the experimental group received 30 minutes of the treatment at the end of their sessions. The treatment was focused on the ten phases of the TASK and the techniques of critical thinking such as writing the ideas on a piece of paper called admit tickets, writing logs based on the taught materials as homework, 
listing and clustering for certain concepts such as internet, and writing focused free-writes on a specific subject like television for about five minutes or so.

After the treatment was done, both groups were asked to write a five paragraph argumentative essay with the subject of Advantages and Disadvantages of Cell-phones, in about 30 minutes. Their papers were all gathered by the researcher, and the same two English teachers scored them based on Unrau's scoring guide.

The following tables are dealing with the statistical figures of the study. In table 1, mean scores of the experimental and control groups in pretest are presented. In table 2, results of the level of significance, t-tests in pretest are shown.

When there are two independent groups, their covariance should be checked. For checking the equality of variances the Levene's Test is used. According to the statistic of Levene's Test (F) which is 0.012 , the level of significance which is 0.912 , and comparing this level of significance with 0.05 , it is obvious that the null hypothesis based on the equality of the variances in two groups is not rejected. So the data of the equal variances assumed, is used for the pretest.

TABLE 1

PRETEST/TOTAL 1

\begin{tabular}{|c|c|c|c|c|c|}
\hline \multicolumn{6}{|c|}{ Group Statistics } \\
\hline & Group & $\mathbf{N}$ & Mean & Std. Deviation & Std. Error Mean \\
\hline \multirow{2}{*}{ PRE_T } & 1 Experimental & 29 & 71.8103 & 11.33690 & 2.10521 \\
\hline & 2 Control & 30 & 72.8667 & 10.67299 & 1.94861 \\
\hline
\end{tabular}

TABLE 2

LEVENE'S TEST 1

Independent Samples Test

\begin{tabular}{|c|c|c|c|c|c|c|}
\hline & & \multicolumn{2}{|c|}{ Levene's Test for Equality of Variances } & \multicolumn{3}{|c|}{ t-test for Equality of Means } \\
\hline & & $\mathbf{F}$ & Sig. & $\mathbf{t}$ & Df & Sig. (2-tailed) \\
\hline \multirow{2}{*}{ PRE_T } & Equal variances assumed & .012 & .912 & -.369 & 57 & .714 \\
\hline & Equal variances not assumed & & & -.368 & 56.493 & .714 \\
\hline
\end{tabular}

According to the statistic of the T-Test which is -0.369 , with the degree of freedom of 57 , the level of significance of 0.714 , and comparing this level of significance with $\alpha=0.05$, it is obvious that the null hypothesis based on the equality of the total mean scores in two groups of experimental and control group is not rejected.

In tables 3 and 5, experimental and control groups' pretest and posttest means and standard deviations are presented respectively. Table 4 and 6 show the experimental and control groups' mean and standard deviation differences, respectively.

In tables 3 and 4 as you can see there is a meaningful difference between pretest and posttest in experimental group; it means the scores are developed and increased.

TABLE 3

EXPERIMENTAL GROUP's PRETEST AND POSTTEST STATISTICS

\begin{tabular}{|c|c|c|c|c|c|}
\hline \multicolumn{6}{|c|}{ Paired Samples Statistics(a) } \\
\hline & & Mean & $\mathbf{N}$ & Std. Deviation & Std. Error Mean \\
\hline \multirow{2}{*}{ Pair 1} & PRE_T & 71.7500 & 26 & 11.75946 & 2.30622 \\
\hline & POS_T & 80.3462 & 26 & 9.98175 & 1.95758 \\
\hline \multicolumn{6}{|c|}{ a GROUP Group = 1 Experimental } \\
\hline
\end{tabular}

TABLE 4

EXPERIMENTAL GROUP's MEAN/STANDARD DEVIATION/STANDARD ERROR MEAN SCORES

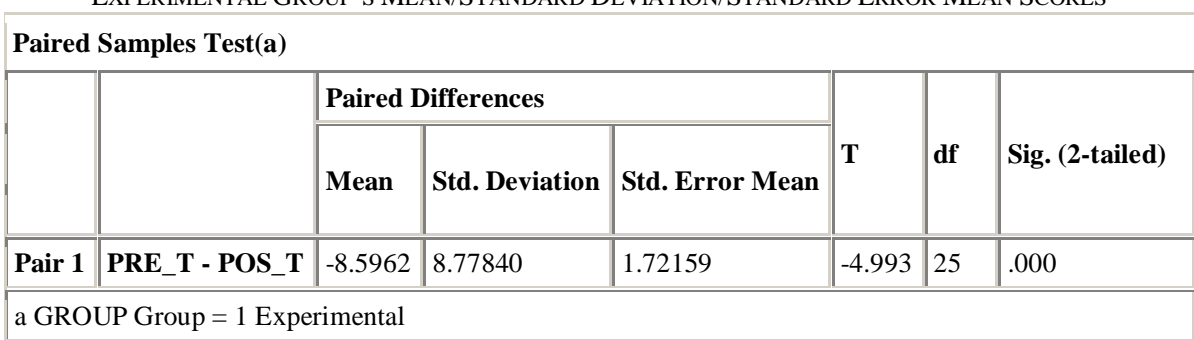

And by considering tables 5 and 6 it is cleared that there is a meaningful difference between pretest and posttest in control group; it means the control groups' scores are increased. 
TABLE 5

CONTROL GROUP's PRETEST AND POSTTEST STATISTICS

\begin{tabular}{|l|l|l|l|l|l|}
\hline \multicolumn{5}{|c|}{ Paired Samples Statistics(a) } \\
\begin{tabular}{|c|l|l|l|l|l|}
\hline & & Mean & N & Std. Deviation & Std. Error Mean \\
\hline \hline \multirow{2}{*}{ Pair 1 } & PRE_T & 73.8393 & 28 & 10.37452 & 1.96060 \\
\cline { 2 - 5 } & POS_T & 79.0893 & 28 & 13.23229 & 2.50067 \\
\hline \hline
\end{tabular} \\
\hline
\end{tabular}

TABLE 6

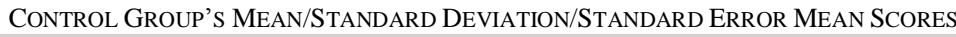

\begin{tabular}{|c|c|c|c|c|c|c|c|}
\hline \multicolumn{8}{|c|}{ Paired Samples Test(a) } \\
\hline & & \multicolumn{3}{|c|}{ Paired Differences } & \multirow[b]{2}{*}{$\mathbf{t}$} & \multirow[b]{2}{*}{ df } & \multirow[b]{2}{*}{ Sig. (2-tailed) } \\
\hline & & Mean & Std. Deviation & Std. Error Mean & & & \\
\hline Pair 1 & PRE_T - POS_T & -5.2500 & 10.36688 & 1.95916 & -2.680 & 27 & .012 \\
\hline \multicolumn{8}{|c|}{ a GROUP Group $=2$ Control } \\
\hline
\end{tabular}

According to statistics the null hypothesis is not rejected, in other words critical thinking does not develop writing sustained argumentative essays by Iranian University EFL students. Based on the statistic of the T-test which is -0.369 , with the degree of freedom of 57, the level of significance of 0.714 , and comparing this level of significance with 0.05 , it is obvious that the null hypothesis based on the equality of the total mean scores in two groups of experimental and control group is not rejected. There is a meaningful difference between pretest and posttest in experimental group; it means the scores are developed and increased. Also there is a meaningful difference between pretest and posttest in control group; it means the control group's scores are increased. But if we compare the experimental and control group with each other there is no significant increase. That is why although there was an improvement; it was not significant to reject the null-hypothesis.

\section{Pedagogical Implications}

Every educational activity should be in harmony with context and the need of the students. In Iran students are not interested in criticism. They are used to receiving their lessons traditionally by traditional teachers who are dominating them in their classes. Here in Iran teacher-centered education is common, and almost all of the students are not familiar with discussions about and criticizing over the stuff they are going to learn in the classrooms.

The remedy to changing teacher-centered education into learner-centered one is familiarizing the students with thinking and thinking critically. If students think critically about the stuff they are facing, they have something to say, they can express themselves, and also they can hear what their classmates say. In this way they share their thoughts, experiences and ideas with the whole class. They learn from each other and the teacher-centered classrooms gradually changes into modern classes where the teachers are no more dominators and they become animators who give life to the class and guide the students instead of imposing them what to do or what not to do.

If critical thinking techniques are taught in the classes, their values and roles can be seen on the essays. Critical thinkers can write argumentative essays.

\section{CONCLUSION}

This study was implemented on the basis of Unrau's TASK and scoring guide (1997). There were two main theories behind this work: reflective language teaching and critical pedagogy. The focus was on teaching techniques of critical thinking to the university freshmen students in order to make them think critically. Then the effect of these techniques was analyzed through writing argumentative essays.

According to statistics, the null hypothesis is not rejected, in other words critical thinking does not develop writing sustained argumentative essays by Iranian University EFL students. According to statistic of the T-test which is -0.369 , with the degree of freedom of 57, the level of significance of 0.714 , and comparing this level of significance with 0.05 , it is obvious that the null hypothesis based on the equality of the total mean scores in two groups of experimental and control group is not rejected (Table 2). As it is shown in tables 3 and 4 there is a meaningful difference between pretest and posttest in experimental group; it means the scores are developed and increased. Also there is a meaningful difference between pretest and posttest in control group; it means the control group's scores are increased. But if we compare the experimental and control group with each other there is no significant increase. That is why although there was an improvement; it was not significant to reject the null-hypothesis. 


\section{REFERENCES}

[1] Bailin, S., Case, R., Coombs, J. R., \& Daniels, L. B.(1999). Common misconceptions of critical thinking. Journal of Curriculum Studies, 31(3), 269-283.

[2] Bowell, T., \& Kemp, G. (2002).Critical thinking: a concise guide. New York: Routledge.

[3] Dewey, J. (1910). How we think. Lexington, MA: D. C. Health.

[4] Farrell, S. C. (2007). Reflective language teaching. London: Continuum.

[5] Feuerstein, M. (1999). Media literacy in support of critical thinking. Learning, Media and Technology, 24(1), 43-54.

[6] Fisher, R. (1990). Teaching children to think. London: Nelson Thorns Ltd.

[7] Freire, P. (1970). Pedagogy of the oppressed. New York: The Continuum International Publishing Group, Inc.

[8] Garrison, D. R. (1991). Critical thinking and adult education: A conceptual model for developing critical thinking in adult learners. International Journal of Lifelong Education, 10(4), 287-303.

[9] Glenn, C. (2004). Making sense: A real-world rhetorical reader. Boston, MA: Bedford/St. Martin's.

[10] Greenlaw, S. A., \& Deloach, S. B. (2003). Teaching critical thinking with electronic discussion. The Journal of Economic Education, 34(1), 36-52.

[11] Jeevanantham, L. S. (2005). Why teach critical thinking? Africa Education Review, 2(1), 118-129.

[12] Kabilan, K. M. (1999). Developing the critical ESL learner: The Freire's way. Paper presented at $5^{\text {th }}$ MELTA International Conference, Petaling Jaya, Selangor, Malaysia.

[13] Kabilan, K. M. (2000). Creative and critical thinking in language classrooms. The Internet TESL Journal, 6(6), June 2000.

[14] Mason, M. (2008). Critical thinking and learning. Australia: Blackwell Publishing.

[15] McGregor, D. (2007). Developing thinking; Developing learning a guide to thinking skills in education. New York: McGrawHill: Education, Open University Press.

[16] Reyes, A. S., \& Vallone, L. T. (2008). Constructivist strategies for teaching English language learners. California: Corwin Press, A Sage Publication.

[17] Sharma, C. (1995). Linguistic factors in critical thinking. Early Child Development and Care, 107(1), 35-43.

[18] Summer, W. G. (1940). Folkways: A study of the sociological importance of usages, manners, customs, mores, and morals. New York: Ginn and Co.

[19] Unrau, J. N. (1997). Thoughtful teachers, thoughtful learners: A guide to helping adolescents think critically. Ontario: Pippin Publishing Corporation.

[20] Warburton, N. (2007). The basics of essay writing. Great Britain: Routledge.

[21] Williams, R. L. (2005). Targeting critical thinking within teacher education: The potential impact on society. The Teacher Educator, 40(3), 163-187.

[22] Wink, J. (2000). Critical pedagogy notes from the real world. New York: Addison Wesley Longman Inc.

[23] Wright, I. (2002). Is that right?: Critical thinking and the social world of the young learner. Ontario, Canada: Pippin Publishing Corporation.

[24] Zainuddin, H., \& Moore, A. R. (2003). Enhancing critical thinking with structured controversial dialogues. The Internet TESL Journal, 9(6), June 2003.

Mansoor Fahim is an associate professor of TEFL at Allameh Tabataba'i University, Tehran, Iran from 1981 to 2008 as a member of the faculty of English Language and Literature at Allameh Tabataba'i University in Tehran, Iran when he retired as an associate professor of TEFL. He has taught English at a welter of universities. At present, he runs Research methods, Psycholinguistics, Applied Linguistics, Second Language Acquisition, and Seminar classes at MA .level and First Language Acquisition, Psycholinguistics, and Discourse Analysis courses at Ph.D. level at a number of universities including Allameh Tabataba'i and Islamic Azad Universities, Science and Research Campus. Moreover, he has several published articles and books mostly in the field of TEFL and has translated some books into Farsi.

Dr. Fahim is currently a member of the editorial board of some Iranian journals of Applied Linguistic Studies.

At present, he runs Research methods, Psycholinguistics, Applied Linguistics, Second Language Acquisition, and Seminar classes at M.A. level and First Language Acquisition, Psycholinguistics, and Discourse Analysis courses at Ph.D. level. He has published several articles and books mostly in the field of TEFL and has translated some books into Farsi.

Pantea Hashtroodi is a Ph.D. candidate in TEFL at the Islamic Azad University, Science and Research Center, Tehran. Her main interests of research are in Psycholinguistics, sociolinguistics, translation, and first and second language acquisition. She holds a B.A. in English Translation and M.A. in TEFL from the Islamic Azad University South-Tehran branch. During her study at B.A. and M.A. she was one of the top students of the university. She has published some articles so far. She has worked in some good institutes in Tehran, and she has the experience of teaching at NIOC exploration as well. In addition she has worked professionally with 5 to 12 years old children at one of the famous institutes in Tehran. 